\title{
Work Integrated Learning Online Enrichment Intervention Programme for Student Teachers
}

\author{
Valencia Tshinompheni Mabalane ${ }^{1}$ \\ ${ }^{1}$ University of Johannesburg, Faculty of Education, Department of Education and Curriculum Studies (ECS), South \\ Africa \\ Correspondence: Valencia Tshinompheni Mabalane, University of Johannesburg, Faculty of Education, Department \\ of Education and Curriculum Private Bag 524 Auckland Park, 2006, South Africa.
}

Received: April 6, 2021

Accepted: June 15, 2021

Online Published: July 14, 2021

doi:10.5430/ijhe.v11n1p59

URL: https://doi.org/10.5430/ijhe.v11n1p59

\begin{abstract}
The study is based on research conducted on work-integrated learning (WIL), also known as teaching practice during the online enrichment and intervention programme for final-year student teachers at a tertiary institution in Johannesburg. This programme was conducted from 2016 and modified in 2020 to enhance and improve the History methodology student teachers' Pedagogic Knowledge and Pedagogic Content Knowledge (PCK), during the Corona virus pandemic using different online tools. Former students of the institution who are now teachers, school learners and a psychologist participated in the process of enhancing the student-teachers' WIL.

The purpose of the study was to explore the effectiveness of the online enrichment intervention programme in providing History student teachers with necessary teaching skills and to ensure readiness for WIL during the Covid -19 period. The main research question was: "To what extent can the online enrichment intervention programmes for student-teachers improve and enhance teaching practice before and during WIL in the context of covid-19?" Qualitative research methods of observation, interviews and document analysis were used with a sample of 90 Post-Graduate Certificate in Education (PGCE) and $4^{\text {th }}$ year Bachelor of Education (BEd) students. The findings indicated that the online enrichment intervention programme improved student-teachers' confidence, emotional readiness before and during WIL and the unfavourable circumstances in their classrooms. Student-teachers reported better understanding of the need for proactive planning for any circumstance or situation. Despite the constraints imposed by the pandemic, they observed changes in their conceptualisation of teaching, improvement in their interaction with learners, in classroom management, in their ability to implement different teaching strategies, resources and assessment tasks.
\end{abstract}

Keywords: corona virus; covid-19, enrichment, intervention; transformative learning, teaching practice, work-integrated learning, student teachers, work integrated learning

\section{Introduction}

The year 2020 became a different and difficult year for everyone in South Africa and the world. The unprecedented Corona virus/Covid-19 pandemic which began in 2020, affected everything; health, the economy, education, politics and social interaction (Dennis, 2020). All sectors were disrupted and succumbed to the demands of the pandemic and had to reimagine their operations. According to Dennis (2020) central to disruption, chaos and the unprecedented pandemic was a need for adjustment and remodelling of all sectors in terms of thinking and planning to align with the demands of the pandemic. Black, Spreen, and Vally (2020) maintain that the advent of the Corona virus pandemic in South Africa illuminated inequalities in schooling and unearthed the problematic role of schools as the focus of social reproduction. Globally, inequalities, readiness and preparedness in the education system were exposed, especially in the public schools and higher education institutions. Accordingly, teacher education was not spared (Cochran-Smith \& Villegas, 2015; Lund \& Eriksen, 2016).

Most current research has indicated the need to transform teacher education "to be future-oriented, innovative, expansive, research-informed, and relevant in ways that may not be found in existing practices" (Lund \& Eriksen, 2016, p. 57). Unfortunately, most institutions of higher education were caught underprepared for the Covid-19 pandemic, including their teacher education schools and faculties. Some institutions still depended on a single mode of teaching instead of blended learning which combines online teaching and on site learning. Dennis (2020) argues 
that the Corona virus has put the spotlight on higher education's outdated financial models, inflexible processes and procedures. This emanates from the argument that traditional teacher education has failed in preparing and equipping future teachers properly for the realities of the classroom (Darling-Hammond, 2006; Korthagen, 2001). In this case, planners and implementers of teacher education were uncertain and undecided about how best to address Work Integrated Learning (WIL). In the institution in question, student-teachers were not equipped with necessary skills for crises and the unprecedented circumstances presented by the pandemic.

\subsection{Literature Review}

According to Korthagen (2001) most teacher education programmes do not allow student-teachers to acquire more than the basic tools for classroom practice and do not equip teachers with emotional intelligence including, "self-awareness, empathy, interpersonal relationships, effective communication, critical thinking, creative thinking, decision-making, problem-solving, and coping up with emotions and stress of teaching and learning" (Goel \& Goel, 2010, p. 24). Most teacher education institutions, I argue, had prepared their student-teachers for the ideal teaching situation with no social and physical restrictions like Covid-19. With the advent of the Corona virus, teacher education programmes are compelled to integrate different skills to ensure that student-teachers are equipped with both the necessary classroom competencies for face to face and remote teaching as well as the required emotional intelligences for the crisis situation. This is emphasised by El Kadri and Roth (2015) who maintain that there is a need for alignment between theoretical and practice-based knowledge to realise the transformative potential of teaching practice.

One can thus infer that lack of any programme alignment with social realities within the education system and community can create problems for student-teachers. For example, the student-teachers in question were not ready for remote teaching and learning, online assessment and analysing online teaching videos because they were used to traditional face to face micro lessons. Oduaran and Mokoena (2015) assert that because teaching is complex, student-teacher programmes should identify and document specific and general forms of effective teacher behaviour that could enhance student performance. All these require high-quality performance and best practice; in other words, teacher professional knowledge (Darling-Hammond, 2006).

The online enrichment intervention introduced for PGCE and BEd students was aimed at developing such knowledge and equipping them with better interaction skills, Pedagogic Content Knowledge (PCK) and other teaching skills necessary for Covid-19 teaching and beyond within the History module/subject. Shulman (1986) describes PCK as the intersection of information about the teacher's subject knowledge and pedagogic knowledge, that is, the skills employed to teach the subject. Furthermore, as the "blending of content and pedagogy into an understanding of how particular topics, problems, or issues are organized, represented, and adapted to the diverse interests and abilities of learners, and presented for instruction" (Shulman, 1987, p. 8).

In this case, a form of collaborative intervention via online tools and with the help of former students who have been through the programme and are now teaching was needed to help student-teachers cope with the Covid 19 challenges. This is a form of supportive, collaborative learning which, according to Leat, Lofthouse, and Taverner (2006), necessitates change in the education environment in order to transform teachers' attitudes, beliefs and professional relations. Furthermore, it is needed to help teachers (student teachers) build a positive self-concept and confidence which prompts innovation in what they do. This study thus posits that change is needed in teacher education programmes to make room for learning and support that can help improve and enhance student teachers' professional learning, specifically during crises of remote learning. This resonates well with the assertion of Oduaran and Mokoena (2015) that good teaching requires that teachers possess knowledge of the theories and judgement that direct what they do, and knowledge of their behaviours.

Accordingly, collaboration will help in this regard, it will alleviate feelings of isolation, detachment and demotivation caused by geographical, physical and historical distance. Student teachers can be afforded an opportunity to work collaboratively with peers they have not seen to support and motivate each other academically and emotionally. Even so, there is no agreement among researchers of the distinctive types of teacher knowledge needed (Beijaard, Verloop, \& Vermunt, 2000; Verloop, Van Driel, \& Meijer, 2001). The implication is that both the theoretical and the practical knowledge bases of the teachers are very important when considering how best to train effective and efficient teachers. Therefore, this leads to the conclusion that appropriate training and preparation is vital to maximise the teachers' capability to function in diverse and mixed classroom contexts (Rytivaara \& Kershner, 2012). To enrich student teachers' skills means that they should be supported to be more reflective teachers who are able to adapt and function in any situation. It implies a change in teaching practice and the incorporation of more 
online support which will ultimately transform their professional practice once they are faced by crises like Covid-19 and when they become full-time teachers (Richardson, 2016).

\subsection{Work-Integrated Learning}

WIL is understood as "an approach to career-focused education that includes classroom-based and workplace-based forms of learning that are appropriate for the professional qualification ... an educational approach that aligns academic and workplace practices for the mutual benefit of students and workplaces" (Council on Higher Education, 2011, p. 4). Teaching practice is a form of WIL, and all components of students' teaching practice must be based on the main features of WIL, even so, these two are sometimes used interchangeably with concepts such as practicum teaching experience (Du Plessis, 2010; Moosa, 2019). It is compulsory for all student teachers in South Africa to do WIL because it affords them an opportunity to put theory into practice in an authentic classroom context, and is a requirement in partial fulfilment of their teaching qualification (Council on Higher Education, 2011).

Providing student teachers, especially those who learn remotely because they are spread throughout the country, with support, supervision and assessment during teaching practice is a challenge (Du Plessis, 2013). This is due to the lack of homogeneity and unclear policy with regard to how teaching practice should be constituted in different institutions (Moosa, 2019). Except for the duration of WIL, which is held in common, all teacher education institutions in South Africa organise their WIL differently. What prompted the online enrichment intervention was the cancellation of the PGCE first teaching experience as a result of the impact of the pandemic. The BEd had been to their first 2020 January WIL over and above those they attended for the past three years of their study. This necessitated the use of online discussion boards, blogs, Zoom and collaborative learning tools for their enrichment and intervention.

Mahlangu (2018, p. 18) argues that "distance learning via e-learning can offer a solution for distance-learning students to further their education while applying new knowledge and skills directly to their practice." He argues that technology can be used as a tool that can be utilised to remove the barriers and challenges present in distance-learning (remote learning) settings. Technology also allows for online videos to be pre-recorded and shared with the rest of the student teachers online (Bell, Douce, Caeiro, Teixeira, Martín-Aranda, \& Oto, 2017). It provides a way of enhancing the learning processes, collaboration and flexibility and for wider dissemination of education and training. It also allows for more effective assessment of content and skills by the institutions, in this case History student teachers. In the same vein, Khumalo (2018) adds that the use of technological resources such as e-resources promotes learning and teaching that assist distant students overcome barriers.

Thus, the purpose of the study was to explore the effectiveness of the online enrichment intervention programme in providing History student teachers with necessary teaching skills and to ensure readiness for WIL during the Covid-19 period. As part of this aim, the study also investigated the impact of the online enrichment intervention programme in enhancing student teachers' teaching practice, before and during WIL in the context of Covid-19. The question asked is: "To what extent can the enrichment intervention programmes for student teachers improve and enhance teaching practice before and during WIL in the context of Covid-19?"

\subsection{Context}

The enrichment intervention, as the name suggests, is the ongoing intervention strategy that started in 2016 to support and enhance History PGCE and BEd $4^{\text {th }}$ year (final) student teachers' classroom practice. The study was necessitated by the negative feedback received from some mentor teachers about the PCK of student teachers and their poor classroom management skills. In 2020, the enhancement intervention programme was adapted to suit the impact and effects of the Covid-19 pandemic on education. PGCE student teachers had been in teacher education for just two months when the unprecedented Corona virus (Covid-19) shut all systems globally. These student teachers had no teaching background or classroom experience as most of them had just completed their undergraduate qualification. All pending micro lessons and their first WIL were cancelled. According to Dennis (2020), central to disruption, chaos and the unprecedented pandemic was a need for adjustment and remodelling of all sectors in terms of thinking and planning to align with the demands of the pandemic.

BEd students were better positioned as compared to their PGCE counterparts because they had been exposed to WIL from the first year of their studies which culminated in January 2020. The programme was instituted twice a month from May 2020 to August 2020 as a means of scaffolding isolated student teachers learning remotely. Former students who are now practising teachers and a psychologist were invited to mentor the student teachers online. Croft, Dalton, and Grant (2010, p. 27) assert that "[t]he physical and temporal separation of tutor and student, and between students themselves, can lead to feelings of isolation." Tools such as Collaborate, Zoom, discussion boards and blogs were used to facilitate the programme. 
The activities comprised of debriefing student teachers with regard to emotional intelligence and teacher behaviour by the educational psychologist, demonstration and analysis of lessons through pre-recorded videos of former student-teachers, recorded role play of lessons by student-teachers and the analysis of past lesson plans. The discussion board and blogs were used to facilitate everyday general questions and interaction amongst student teachers on any topic of their choice and to analyse videos, present lessons and any other formal activity assigned to student teachers - for example classroom management challenges using Zoom - and Classroom Collaborate to connect with teachers, learners and the psychologist. Former student teachers availed their learners (school and parents' permission granted) to participate as a means of providing feedback about their experiences and expectations of student teachers. Student teachers were afforded an opportunity to analyse the pre-recorded videos and their role-played videos with the help of the practising teachers. These were discussed through groups on the blogs, discussion board, Zoom and Classroom Collaborate.

\section{Theoretical Framework}

To enhance the student teachers' teaching practice, the researcher believes that they should transform as individuals first and have an understanding of how they relate to others, how they see knowledge and how they believe knowledge is constructed. Lund and Eriksen (2016, p. 53) argue that "the principles of transformative agency offer a conceptual framework for studying changes in teacher education and can contribute to the understanding of how we can design future-oriented study program." The researcher wanted student teachers to critically reflect on their teaching practice so that they could alter their teaching practices where necessary. This study, therefore, employed the Transformative Learning Theory (Mezirow, 1994) and constructivism embedded in transformative learning as it is reflective in nature and central to the way learners interpret and reinterpret their experiences to make meaning. Mezirow (2009) defines transformative learning as learning that transforms challenging frames of reference to make them more all-inclusive, reflective, open and emotionally able to modify, adjust and alter their world view and experiences.

Mezirow uses this theory to show how individuals or people develop and use critical self-reflection to deal with their worldviews or beliefs and experiences in order to transform their perspectives on life. Thus, this theory formed the basis for the planning of the enrichment support programme for student teachers to critically self-reflect on their previous teaching practice so that they could make changes which would eventually lead to new learning - this is called the 'disorientation dilemma' (Kitchenham, 2008; Mezirow, 2009). This lens was used to assist student teachers in reconstructing and transforming their beliefs about how they teach, manage their classrooms and care for themselves (Christie, Carey, Robertson, \& Grainger, 2015). Individuals' personal accumulated experiences can be used as the frame of reference for any activity or engagement. Mezirow (2009) calls these 'meaning perspectives' and divides them into three categories: psychological personal codes which are views and beliefs held about ourselves, who we are and what we can do as individuals; the sociolinguistic/ sociocultural code - how one views the world and how beliefs about the world and society are organised in terms of issues such as race, gender, religion and how they function; and the epistemological code - one's belief about knowledge and how it is generated and organised. In other words, the way individuals see themselves, others and knowledge will determine the way the new information or learning will be interpreted.

Bandura $(1981,1982,1986)$ emphasises similar views, stating that it is crucial for individuals to have self-efficacy. He theorised that beliefs are closely connected to behaviour and defines self-efficacy as "judgements of how well one can execute courses of action required to deal with prospective situations" (Bandura 1982, p. 22). In terms of teachers, this means the teachers' beliefs held about their ability reflected in their teaching. He describes the four sources of efficacy that impact on teacher self-efficacy as, mastery experience, vicarious experience, verbal persuasions/feedback and psychological factors or emotional arousal (Bandura, 1986). It is these three meaning perspectives that were reconstructed and transformed through the enrichment intervention for the student teachers. The meaning perspectives were used to guide the study because, according to this theory, every learning experience is always shaped by these three codes which serve as the mode of interpretation in new contexts. Thus, transformative learning occurs when individuals change their perspectives or view of the world as they encounter new knowledge (Kitchenham, 2008).

\section{Research Design and Methods}

The study employed a qualitative research paradigm in order to explore the effectiveness of the online enrichment intervention programme, to understand and gain insight into student teachers' opinions, their personal experiences and how they interpreted the impact of the enrichment programme (Creswell, 2007; Flick, 2008; Lincoln, 2005). Ethnography situated in the constructivist-interpretive paradigm was used as the research design for this study (Best, 
Flick, \& Kahn, 2003; Denzin \& Lincoln, 2011; Henning, Van Rensburg, \& Smit 2004). Three categories of people were invited to participate:

- $\quad$ educational psychologist who dealt with the personality aspects and for boosting morale;

- former History student teachers who are currently teaching and had classroom experience were invited to share their first-hand experiences with regard to classroom and teaching practice, using recorded teaching videos and other online tools as mentioned above.

- Learners from different schools who shared their experiences of student teachers and what their expectations were about their classroom practice.

Therefore, purposive sampling was employed, and all the participants were $4^{\text {th }}$ year BEd and PGCE students (Kvale, 2007; Lincoln, 2005). Some $4^{\text {th }}$ year BEd and PGCE student teachers had developed anxiety as a result of having feelings of inadequacy to teach and feared what I termed 'Covid-19 classrooms'. All these student teachers attended the online enrichment intervention programme, but for the purpose of this study, only 90 students teachers participated in the study out of 148 PGCE and BEd student teachers. Twenty seven out of 38 PGCE and 63 BEd student teachers made up of 42 males and 58 females ranging in ages from 21 to 32 constituted the sample.

Data was collected through 62 observations of recorded video lessons, role plays, online micro lessons, 46 Zoom semi-structured, individual interviews; and two focus-group interviews conducted for one and a half hours per session. In addition, documents such as lesson plans and student teachers' WIL reports were analysed. The methods were triangulated to afford student teachers an opportunity to express their personal accounts of experiences and feelings about the online enrichment programme using a predesigned interview schedule with open-ended questions (Marshall \& Rossman, 2006). Student teachers' were asked for permission to participate in the research and the consent was granted. Therefore, the following was ensured: their anonymity was respected; they were allocated pseudonyms; consent forms were signed, and confidentiality was observed.

Content analysis (Merriam, 2002) was employed to analyse all data collected with regard to the online enrichment intervention programme, to see how the three codes of transformational learning (i.e., the psychological, sociolinguistic/sociocultural code and epistemelogical codes) were applied, and to see how they constructed knowledge. The three codes of transformational learning were used to interpret student teachers' collected data. The researcher focused deeply on the meaning of student teachers' data sets by analysing words or certain activities and evaluating their experiences with regard to the enrichment programme (Graneheim \& Lundman, 2004).

Each student teacher's responses were analysed separately in order to elicit the uniqueness of their experiences and meaning (Gibbs, 2007; Ryan \& Bernard, 2003). The comparison of the data sets was conducted to identify the thread of similarities and differences among them. Throughout the process of data analysis, data was coded, manually categorised, and then the categories were reviewed and grouped in accordance with the three meaning perspectives and the support to student teachers. After reviewing, the researcher relabelled the categories that contained the same or similar meanings and then determined the general patterns in all the themes which emerged. The core themes that emerged from the data sets are the following: improved self-concept and confidence, personal growth and development of student teachers, the significance of collaborating with practising teachers as a means of support, improved interaction between student-teachers and learners, enhanced collaboration with fellow student-teachers, and improved student-teachers' PCK.

\subsection{Discussion and Findings}

The findings revealed that the lectures, micro-lessons and theory are key to the preparation of the student teachers for teaching practice. But also that these activities are not sufficient as some student teachers needed to be exposed to first-hand experience by those who are in practice. Both groups of student teachers hailed the importance and benefits of the enrichment intervention programmes. One of the PGCE students said:

B5: "I have been impacted positively, injected with motivation and knowledge. I learnt everything in one space from the most relevant people. Reality versus imagination. The workshop has given me a sense of power and security beyond anything I could ever imagine. I have learnt the art of creativity and bringing enthusiasm in the classroom as well as combining multiple teaching strategies in order to enhance learning in the classroom."

These feelings are supported by Goel and Goel (2010) who state that innovativeness should be encouraged in teacher education such as new teaching strategies, so that student teachers can be self-motivated, industrious and self-confident. Thus, teacher education should prepare student teachers for the reality of the classroom and they should "acquire more than just practical tools for managing classroom situations" (Korthagen \& Kessels, 1999, p. 2) 
which supports the 'meanings perspectives' of Mezirow (2009). Having been involved in the enrichment support programme, $88 \%$ of the student teachers were able to reflect on their confidence, self-worth, self-motivation, emotional problems, pains, fears, self-doubt, lack of confidence to name a few (psychological code). Furthermore, $63 \%$ were able to reflect on their relationship with others and how they perceived people different from them (sociolinguistic/sociocultural code) while $92 \%$ reported having experienced change and transformation in their lives and perceptions of teaching. They experienced general personal growth, developed relationships with fellow student teachers and changed their general view of teaching as a whole (epistemological code).

\subsection{The Psychological Code}

\subsubsection{Improved Self-Concept and Confidence}

Most student-teachers indicated that their wellbeing needed to be addressed due to anxiety caused by teaching and standing in front of learners. Zembylas (2003) states that student teachers may react to feedback by adopting a self-preservation stance due to the kind of feedback they receive from their mentor teachers. Thus, they received an emotional boost from the programme, at the same time, their self-concept and confidence were restored.

B62: "As teachers, it is important that we look after ourselves as well. Often, we neglect ourselves ... We need to constantly check on ourselves to see if we are doing the utmost best that we can be doing."

B17: "Firstly I have grown personally, emotionally, spiritually ... and I have learnt a lot more than the past three years ... I have learnt to be emotionally balanced and to look after myself in all aspects."

One would have expected the student-teachers to have focused on their PCK growth, instead they indicated that they also needed to deal with those issues affecting their wellbeing. Cattley (2007) indicates that the emotional experiences of student teachers and the nature of feedback given on their teaching skills play a part in the development of self-efficacy. The psychological preparation of student teachers may be overlooked in preparing students for teaching practice as the focus is usually on PCK. This is what they had to say:

P1: “... However, by listening to the experiences offered, it provided relief and practicality that I can apply in my own life if ever I confront certain issues within school. The advice and guidance given prepared me mentally for the weeks ahead. It gave me confidence to use my own abilities and to make them work in my classroom."

B8: "The thing that improved most is my confidence. I was so terrified about WIL 3 because I did not know what to expect, but after this attendance, I am more at ease for I know what is expected of me ..."

P7: “... emotional intelligence was also necessary ... it is important for History teachers mainly because they deal with a subject which sometimes can have distorted information...it deals with real life events and is full of controversial issues."

Bullough and Gitlin (2001) state that the tension between what a particular context demands of teachers (in this case student teachers) and who they are or want to become results in confusion and loss of their identity and leads to them doubting their ability asking: "Can I be who I am in the classroom?" They also argue that it is important for (student) teachers to know who they are and where they stand - making 'self' central to teachers' pre-service preparation before entering the profession.

\subsubsection{Personal Growth and Development of Student Teachers}

According to Goel and Goel (2010, p. 24):

Teacher Education for preparing humane and professional teachers needs to be holistic. Along with content and methodology, there is also a need to integrate emotional competencies, such as self-awareness and self-management, social sensitivity and social management. It is also essential to integrate life skills, such as self-awareness, empathy, interpersonal relationship, effective communication, critical thinking, creative thinking, decision-making, problem-solving, and coping up with emotions and stress with teaching and learning.

This argument confirms the findings and the utterances of student-teachers with regard to their need for teaching practice. It was evident that $79 \%$ of the student-teachers had personal issues that hampered their teaching practice and performance. Most students were not aware of the impact of their emotions in relation to their classroom practice. P13 stated:

"Being able to manage your emotions will lead to positive ways in which one can relieve stress. I have learnt that being emotionally aware of my emotions can help me communicate effectively... I have to be emotionally aware of my feelings in order to be able to overcome each challenge I come across, whether professional or social challenges." 
During the interview, it became clear that past experiences had a negative impact on student teachers and on how they related to others. For example, some student teachers indicated emotional baggage from a dysfunctional childhood which affected their personality and teaching negatively.

P15: “... emotional intelligence and arrested emotional development by the psychologist... They have helped me as a person to observe my reaction towards the different situations in life and how I treat people at large. This will also help me to avoid transferring my childhood experiences to my learners but deal with issues in my personal life so that my teaching will not be affected."

Van Veen, Sleegers, and Van de Ven (2005) found that teachers' negative emotions ranged from anger, shame and anxiety to guilt, depending on the situations they were facing and the lack of support from colleagues, school management and government. On the other hand, positive emotions emerged when teachers took control of their problems and realised their goals and opportunities to improve their teaching practice and strengthen their professional identity. They showed different emotions at different stages of their personal lives and training.

\subsubsection{Sociolinguistic/Sociocultural Code}

The findings revealed that student teachers found mentoring by and collaboration with practising teachers, their peers - fellow BEd and PGCE students - and learners beneficial to their growth. They also mentioned that the collaboration enhanced their teaching practice because they were able to learn from each other. Student teachers spoke of the importance of having first-hand information from people with experience as very important, especially practising teachers who had gone through the same teacher education programme. The enrichment programme was compared to lecturing, online tutoring and micro-lessons.

\subsubsection{The Significance of Collaborating with Practising Teachers as A Means of Support}

Student teachers referred to practising teachers as 'legends', appreciated their participation and mentoring. This is echoed in the following excerpts which shows how the interaction with practising teachers positively impacted them.

P3: "The most part of the three days was good. The advice from our legends was insightful, telling us what to expect from learners, ... I learnt a lot ... this experience impacted me in a good way, I had to go home and do an introspection to find out what kind of a teacher am I and how can I change ... I realised I have to be a teacher not a friend to my learners so that they can respect me."

2020/P.4 "..what seemed impossible due to this corona... I mean mixing with others was made possible by online interaction with people I don't know but who care."

B7: “... previous students .... share their own experiences of teaching ... through listening to what they have been through, my eyes were truly opened ... Hearing actual teachers' experiences was beneficial to me as times have changed ... Through this seminar I feel as if I have an advantage with knowledge and insight ... and proper intense teaching... they added so much value to my teaching."

Turbill and Kervin (2007) agree by emphasising that student teachers have to be supervised by mentors and experience the real situation so as to create the link between teacher education and the school as a workplace. They can also learn how to become part of the school community by developing a professional, collegial relationship with fellow teachers in a non-threatening environment.

\subsubsection{Enhanced Collaboration with Fellow Student Teachers}

All participants appreciated the interaction with fellow student teachers. They viewed it as a breakthrough and a means to collaborate beyond boundaries of qualifications, and stated the following:

P6: "Interaction with my fellow students was great, and we were able to share ideas and strategies in which we can engage all the learners in a lesson. I now know almost all of my fellow students, and I believe we will share ideas and experiences in future."

B7: "Interaction with fellow students created a conducive learning and teaching environment because it was productive through exchanging different teaching ideas, innovative teaching methods because it initiated a new way on how to exchange teaching strategies that will grab and arouse interest among learners ..."

B22: "Another thing that was good is the notion of 'us and them' between the BEd 4th year and the PGCE students or class was addressed. We learnt from each other and made friends."

The importance of collaboration is echoed by Rytivaara and Kershner (2012) who support co-teaching and joint knowledge construction as a context for teachers' learning. They also argue that co-teaching has the potential to support teachers in addressing their professional responsibilities. 


\subsubsection{Improved Interaction between Student Teachers and Learners}

Goel and Goel (2010) state that it is essential to change traditional, rigid, directional, teacher-centred learning to more powerful learning paradigms, such as learner-centred teaching and also narrow the gap between teaching styles and learning styles by providing differentiated learning experiences to accommodate all learners. This is supported by student teachers who welcomed the involvement of learners as a way of accommodating learning styles and reflecting on their practice. Accordingly, $81 \%$ of the student teachers' views of learners as empty vessels were transformed:

P33: "My mindset of learners being perceived as people who have less knowledge was also changed through the engagement with the high school learners. One discovered that learners have a lot of knowledge to share and the perception of taking learners as people with less or no knowledge of their education is a disadvantage to them as the teacher because they are not empty human beings. They too have something to share and, therefore, a teacher can also learn from his or her learners."

B7: "It was such an honour to have actual learners from a high school come down and talk to us about what they expect from History teachers.

This confirms that teachers who intentionally collaborate with their learners to share responsibility for coaching, decision-making, support and encouragement offer their learners a voice to make choices, solve problems among themselves and peers, and become able to consider different ideas. Furthermore, teachers who collaborate with their learners also give them choices, power and control over problematic behaviour and promote higher levels of learning or mastery (Villa, Thousand, \& Nevin, 2010).

\subsection{Epistemological Code}

Student teachers reported a paradigm shift in their teaching practice and indicated that their view of teaching practice and PCK had changed. Most participants (78\%) indicated that they learnt that History teaching was not just the narration of past events but also allowed learners to interrogate the content and to think critically. The complexity of preparation of teachers is echoed by Lund and Eriksen (2016) who agree that, since teachers work in increasingly complex learning environments characterised by multicultural and technology-rich dimensions, a solid knowledge base is needed. When asked to reflect on the enrichment programme, PGCE 2020/N4 said:

"The challenges that I experience are that there are many students and few classrooms, the learner share all the materials. There is no social distance at all. This is because the school is under maintenance therefore it is very dirty. During learning and teaching I struggle because I have to shout as children do not hear me properly. I do not feel comfortable in the school because most learners do not cover their face by masks."

P9: "Change is the end result of all true learning. We are all taught before but the way we prepared for it is usually from one perspective. The reason for that is mainly because we are not given the opportunity to get into the true nature of the schooling system."

PGCE 2020/D6: There are three main aspects that stood out for me. Firstly, that History teachers need to make content relevant to learners. Secondly, I should be able to tell them the importance of studying History, and lastly, I need to be very descriptive... Furthermore, the learners highlighted the importance of having a History classroom that transported them back into time."

In other words, it is important to ensure that student teachers are well prepared before entering the profession even if it means learning outside the university lectures to help support and expand their learning (Siebert, 2005).

\subsubsection{Enhanced Student Teachers' PCK}

Most participants (78\%) also indicated that the enrichment intervention programme also helped them with regard to teaching strategies and skills in History as evidenced in the following interview excerpts:

B19: "The workshop... provided me with the know-how on the preparation that goes behind various teaching strategies, particularly the use of technology in the History classroom."

B45: "The enrichment programme was fruitful and educative because it exposed me to different techniques and teaching expectations that teachers must inculcate the culture of different teaching strategies, teaching aids, assessment technological tools ... which form the engine of teaching and learning as a way of delivering quality education ..."

Oduaran and Mokoena (2015) agree with other authors that the kind of teacher needed today is one who is holistically equipped with necessary teaching skills, is open to new ideas in areas related to classroom practice, has 
good PCK, and is able to include technology in their teaching methodology. B53 explained the change in her classroom management skills, as follows:

"These ... have truly been an enriching experience. I gained a lot of insight about what it is going to be like in the teaching world... I have had a few troubles in the past with managing my classroom but speaking to teachers who deal with those difficulties, especially with Covid -19 on a day to day basis gives me a lot of hope in this career."

PGCE W/14: "The classrooms and the school can sometimes have a "creepy" and "eerie" feel to it, now that only half of the school attends and there is no grade 12's... The teaching aspect is going great and the school has provided me with a face shield so that I can talk and be heard better by the learners. The only problem that we face is that each lesson will have to be taught six times over instead of the regular three. This means that there is not enough time for the work to be completed."

West-White (2007, p. 113) concurs with Lenevan that:

"Competent teachers who are well versed in classroom management and organisation and use multiple teaching methods to accommodate students' learning style preferences; whereas, novice teachers who are not so well versed are not able to endure the complexities and multiple dynamics of teaching."

\section{Conclusion}

This study explored the impact of the enrichment programme through Mezirow's transformative learning theory using the three meaning perspectives: psychological personal code, the sociolinguistic/sociocultural code and the epistemological code. In particular, the study focused on the development of the teaching practice and the PCK of History student teachers who were not sure if they would go on WIL during Covid-19. The enrichment support programme revealed the hidden personal challenges student teachers experienced as a result of their past and these were transferred to their classrooms, consequently impacting their teaching negatively. Again, it was shown that these student teachers felt isolated due to Covid-19 during WIL and needed support from the institution. Mukeredzi (2017, p. 2) states that "Student mentoring during practicum constitutes a critical factor in their professional learning and development." Student teachers reported that they wanted the institution to create an online programme wherein they could collaborate and interact with each other, lecturers and the WIL coordinator when they were confronted by challenges during WIL. They viewed the online discussion board, ultra-collaboration and blogs as good tools for communication during WIL.

- Psychological personal code - student teachers experienced personal growth and self-efficacy which they lacked before. Instead of equipping student teachers with planning and teaching skills only, the programme helped them to reflect on and address their past pain and fears. It was also revealed that the student teachers needed to deal with their personalities, emotions and levels of confidence.

- Sociolinguistic/sociocultural code - student teachers benefited from collaboration and interaction with learners, practicing teachers and their fellow PGCE and BEd student-teachers - which is a rare collaboration - to help them prepare for their WIL that formed a community of practice important during this time.

- Epistemological code - student teachers' paradigm shifted with regard to their PCK. The analysis of the role play and recorded videos of practicing teachers and online quizzes related to classroom management changed their teaching perspectives. However, the context of the classroom with regard to masks, grade rotational class attendance, and social distancing constrained their potential to practice their best teaching abilities as they had to improvise and adapt their PCK.

Scholars (Cochran-Smith \& Villegas, 2015; Oduaran \& Mokoena, 2015; Lund \& Eriksen 2016) call for teacher education to transform and keep abreast with the contextual needs and demands of the society. This necessitates that institutions, dealing with student teachers, establish strong supportive structures that will ensure the wellbeing and success of student teachers before, during and after WIL, especially during the time of Covid-19. It is also of utmost importance that student teachers who are faced with uncertain circumstances and challenging contexts be provided with a support system ranging from academic and psychological support to technological skills development. This will contribute to breaking the isolation of student teachers in remote areas, lessen their performance anxiety while potentially enhancing their practice in ways that may not have been possible in pre-pandemic circumstances.

\section{References}

Bandura, A. (1981). Self-referent thought: A developmental analysis of self-efficacy. Social Cognitive Development: Frontiers and Possible Futures, 200(1), 239. 
Bandura, A. (1982). Self-efficacy mechanism in human agency. American Psychologist, 37(2), 122. https://doi.org/10.1037/0003-066X.37.2.122

Bandura, A. (1986). The explanatory and predictive scope of self-efficacy theory. Journal of Social and Clinical Psychology, 4(3), 359-373. https://doi.org/10.1521/jscp.1986.4.3.359

Beijaard, D., Verloop, N., \& Vermunt, J. D. (2000). Teachers' perceptions of professional identity: An exploratory study from a personal knowledge perspective. Teaching and Teacher Education, 16(7), 749-764. https://doi.org/10.1016/S0742-051X(00)00023-8

Bell, S., Douce, C., Caeiro, S., Teixeira, A., Martín-Aranda, R., \& Otto, D. (2017). Sustainability and distance learning: a diverse European experience? Open Learning: The Journal of Open, Distance and E-Learning, 32(2), 95-102. https://doi.org/10.1080/02680513.2017.1319638

Best, J. W., \& Kuhn, J. V. (2003). Research in education (9th ed..). Boston: Aflyn and Bacon.

Black, S., Spreen, C., \& Vally, S. (2020). Education, Covid-19 and care: Social inequality and social relations of value in South Africa and the United States. Southern African Review of Education, 26(1), 40-61.

Bullough, R. V., \& Gitlin, A. (2013). Becoming a student of teaching: Linking knowledge production and practice. Routledge. https://doi.org/10.4324/9781315023243

Cattley, G. (2007). Emergence of professional identity for the pre-service teacher. International Education Journal, $8(2), 337-347$.

Clark, R. C., \& Mayer, R. E. (2016). E-learning and the science of instruction: Proven guidelines for consumers and designers of multimedia learning. London, England: John Wiley \& Sons. https://doi.org/10.1002/9781119239086

Christie, M., Carey, M., Robertson, A., \& Grainger, P. (2015). Putting transformative learning theory into practice. Australian Journal of Adult Learning, 55(1), 9-30.

Cochran-Smith, M., \& Villegas, A. M. (2015). Framing teacher education research: An overview of the field, part 1. Journal of Teacher Education, 66(1), 7-20. https://doi.org/10.1177/0022487114549072

Council on Higher Education. (2011). Work integrated learning: Good practice guide. Pretoria, South Africa: CHE.

Creswell, J. N. (2007). Qualitative inquiry research and design: Choosing among five traditions. London, England: SAGE.

Croft, N., Dalton, A., \& Grant, M. (2010). Overcoming isolation in distance learning: Building a learning community through time and space. Journal for Education in the Built Environment, 5(1), 27-64. https://doi.org/10.11120/jebe.2010.05010027

Darling-Hammond, L. (2006). Constructing 21st century teacher education. Journal of Teacher Education, 57(3), 300-314. https://doi.org/10.1177/0022487105285962

Dennis, M. J (2020). Inside higher ed. 1150 Connecticut Avenue NW, Suite 400 - Washington, DC 20036, 14 September 2020,

Denzin, N. K., \& Lincoln, Y. S. (2005). The SAGE handbook of qualitative research (3rd ed.). Thousand Oaks: Sage. https://doi.org/10.1177/1468794105047237

Du Plessis, E. (2010). Students' experiences of work-integrated learning in teacher education. Progressio, 32(1), 206-221.

Du Plessis, E. (2013). Mentorship challenges in the teaching practice of distance learning students. The Independent Journal of Teaching and Learning, 8(1), 29-43.

Du Plessis, E. C. (2017). The voices of student teachers on e-learning initiatives in a distance education community of practice.

El Kadri, M. S., \& Roth, W. M. (2015). The teaching practicum as a locus of multi-leveled, school-based transformation. Teaching Education, 26(1), 17-37. https://doi.org/10.1080/10476210.2014.997700

Flick, U. (2007). Managing quality in qualitative research. The SAGE qualitative research kit. London, England: SAGE. https://doi.org/10.4135/9781849209441

Gibbs, G. (2007). Analyzing qualitative data. The Sage qualitative research kit. London, England: SAGE. https://doi.org/10.4135/9781849208574 
Goel, D. R., \& Goel, C. (2010). Innovations in teacher education. Journal of Engineering, Science and Management Education, 1, 24-28.

Graneheim, U. H., \& Lundman, B. (2004). Qualitative content analysis in nursing research: Concepts, procedures and measures to achieve trustworthiness. Nurse Education Today, 24(2), 105-112. https://doi.org/10.1016/j.nedt.2003.10.001

Henning, E., Van Rensburg, W. A., \& Smit, B. (2004). Finding your way in qualitative research. Pretoria, South Africa: Van Schaik.

Joubert, Y. T., \& Snyman, A. M. (2017). Challenges experienced with online tutoring in an ODL institution. Progressio, 39(1), 126-145. https://doi.org/10.25159/0256-8853/2139

Khumalo, S. S. (2018). Improving student success rate in open distance learning settings through the principle of constructive alignment. Trends in E-learning, 31. https://doi.org/10.5772/intechopen.75637

Kitchenham, A. (2008). The evolution of John Mezirow's transformative learning theory. Journal of Transformative Education, 6(2), 104-123. https://doi.org/10.1177/1541344608322678

Korthagen, F. A. J. (2001, April). Linking practice and theory: The pedagogy of realistic teacher education. Paper presented at the Annual Meeting of the American Educational Research Association, Seattle 2001, 10-14 April. Retrieved from: http://citeseerx.ist.psu.edu/viewdoc/download?doi=10.1.1.92.1562\&rep=rep1\&type=pdf

Korthagan, F. A. J., \& Kessels, J. (1999). Linking theory and practice: Changing the pedagogy of teacher education. Educational Researcher, 28(4), 4-17. https://doi.org/10.3102/0013189X028004004

Kvale, S. (2007). Doing interviews. The SAGE qualitative research kit. London, England: SAGE. https://doi.org/10.4135/9781849208963

Larkin, D. B. (2013). Deep knowledge: Learning to teach science for understanding and equity. New York, NY: Teachers College Press.

Leat, D., Lofthouse, R., \& Taverner, S. (2006). The road taken: Professional pathways in innovative curriculum development. Teachers and Teaching: Theory and Practice, 12(6), 657-674. https://doi.org/10.1080/13540600601029686

Lincoln, N. K. D. Y. S. (2005). The Sage handbook of qualitative research. Sage.

Lund, A., \& Eriksen, T. M. (2016) Teacher education as transformation: Some lessons learned from a center for excellence. Education Acta Didactica Norge, 10(2), 53-72. https://doi.org/10.5617/adno.2483

Lund, A., \& Eriksen, T. M. (2016) Teacher education as transformation: Some lessons learned from a center for excellence. Education Acta Didactica Norge, 10(2), 53-72. https://doi.org/10.5617/adno.2483

Mahlangu, V. P. (2018). The good, the bad, and the ugly of distance learning in higher education. Trends in E-learning, 17-29. https://doi.org/10.5772/intechopen.75702

Marshall, C., \& Rossman, G. B. (2006). Designing qualitative research (4th ed.). New Delhi, India: SAGE.

Merriam, S. B. (2002). Qualitative research in practice: Examples for discussion and analysis. San Francisco, CA: Jossey-Bass.

Mezirow, J. (1994). Transformative learning theory. Understanding and promoting transformative learning: A guide for educators of adults. San Francisco, CA: Jossey-Bass.

Mezirow, J. (2009). Transformative learning theory. In J. Mezirow, \& E. W. Taylor (Eds.), Transformative Learning in Practice: Insights from Community (pp. 18-32). San Francisco, CA: Jossey-Bass.

Moosa, M. (2019). Reducing practice-shock: First-year student teachers' experiences of a campus-based teaching practice model. Journal of Education, 77, 94-114. https://doi.org/10.17159/2520-9868/i77a06

Mukeredzi, T. G. (2017). Mentoring in a cohort model of practicum: mentors and preservice teachers' experiences in a rural South African school. SAGE Open, 7(2), 2158244017709863. https://doi.org/10.1177/2158244017709863

Oduaran, A., \& Mokoena, M. A. (2015). Teacher professional knowledge and teaching in the 21st century. In M. J. Taole (Ed.), Teaching practice, perspectives and frameworks. Pretoria, South Africa: Van Schaik.

Richardson, V. (2016). Significant and worthwhile change in teaching practice. Educational Researcher, 19(7), 10-18. https://doi.org/10.3102/0013189X019007010 
Ryan, G. W., \& Bernard, H. R. (2003). Data management and analysis methods. In N. K. Denzin, \& Y. S. Lincoln (Eds.), Collecting and interpreting qualitative materials (2nd ed.). Thousand Oaks, CA: SAGE.

Rytivaara, A., \& Kershner, R. (2012). Co-teaching as a context for teachers' professional learning and joint knowledge construction. Teaching and Teacher Education, 28(7), 999-1008. https://doi.org/10.1016/j.tate.2012.05.006

Schön, D. A. (1991). The reflective turn: Case studies in and on educational practice. New York, NY: Teachers Press, Columbia University.

Shulman, L. S. (1986). Those who understand: Knowledge growth in teaching. Educational researcher, 15(2), 4-14. https://doi.org/10.3102/0013189X015002004

Shulman, L. S. (1987). Knowledge and teaching: foundations of the new reform. Harvard Educational Review, 57(1), 1-21. https://doi.org/10.17763/haer.57.1.j463w79r56455411

Siebert, C. J. (2005). Promoting preservice teachers' success in classroom management by leveraging a local union's resources: A professional development school initiative. Education, 125(3), 385-393.

Turbill, J. B., \& Kervin, L. K. (2007). Developing a professional identity: First year preservice teachers in school experience project. In J. Kiggins, L. K. Kervin, \& J. Mantei (Eds.), Quality in teacher education: Considering different perspectives and agendas. Wollongong, New South Wales: Australian Teacher Education Association.

Van Veen, K., Sleegers, P., \& Van de Ven, P. H. (2005). One's teacher identity, emotion, and commitment to change: A case study into the cognitive-affective process of a secondary school teacher in the context of reforms. Teaching and Teacher Education, 21, 917-934. https://doi.org/10.1016/j.tate.2005.06.004

Verloop, N., Van Driel, J., \& Meijer, P. (2001). Teacher knowledge and the knowledge base of teaching. International Journal of Educational Research, 35(5), 441-461. https://doi.org/10.1016/S0883-0355(02)00003-4

Villa, R. A., Thousand, J. S., \& Nevin A. I. (2010). Collaborating with students in instruction and decision making: The untapped resource. Thousand Oaks, CA: Corwin Press. https://doi.org/10.4135/9781483388052

West-White, C. (2007). Classroom management: implications for teacher preparation programs and student teachers. Florida Association of Teacher Educators Journal, 1(7), 109-135.

White, S., \& Forgasz, R. (2016). The practicum: The place of experience? In J. Loughran, \& M L. Hamilton (Eds.), International handbook of teacher education (pp. 231-266). Singapore: Springer. https://doi.org/10.1007/978-981-10-0366-0_6

Zembylas, M. (2003). Caring for teacher emotion: Reflections on teacher self-development. Studies in Philosophy and Education, 22(2), 103-125. https://doi.org/10.1023/A:1022293304065

\section{Copyrights}

Copyright for this article is retained by the author(s), with first publication rights granted to the journal.

This is an open-access article distributed under the terms and conditions of the Creative Commons Attribution license (http://creativecommons.org/licenses/by/4.0/). 